Pegem Journal of Education \& Instruction, 4(2), 2014, 25-44

Pegem Eğitim ve Öğretim Dergisi, 4(2), 2014, 25-44

www.pegegog.net

\title{
A Model Proposal Regarding to Reconstruction of Subsystem of Education Supervision in Turkey
}

\author{
Hasan Basri MEMDUHOĞLU ${ }^{* a}$, Abdulhakim TAYMUR ${ }^{\text {b }}$ \\ ${ }^{a}$ Yüzüncü Yıl University, Faculty of Education, Van/Turkey \\ ${ }^{b}$ Provincial Directorate of National Education, Van/Turkey
}

\section{Article Info}

DOI: $10.14527 /$ pegegog.2014.008

Article history:

Received 18 September 2013

Revised 02 January 2014

Accepted 03 February 2014

Keywords:

Supervision,

Education supervision

Supervision model.

\begin{abstract}
The aim of this study is to develop a model for the sub-system of education supervision in Turkey and to put forth how the developed model is adopted and applicable by the education supervisors. The population of this study in which qualitative and quantitative research design are used together, includes education supervisors working all across Turkey. The sample of the present study is composed of 555 education supervisors selected in two provinces of each geographic region. Within the scope of the survey, a model has been developed for the education sub-system in Turkey and this model has been offered to the education supervisors' opinion. In the study, it is concluded that the education supervisors have completely adopted the offered model for the Turkish education system and considered it as applicable.
\end{abstract}

\section{Introduction}

In Turkey for many years education supervision had been performed with a perspective of checking and inspecting the teachers for their misbehaviors. In many applied researches the encountered problems in education supervision have been emphasized. Most of these researches featured problematical of model in education supervision, structure and organization. Besides being attached to the national education directors in provinces, doing a control-oriented formal audit instead of counseling, comforting and development-based audit, to be given to supervisors widely divergent and conflicting roles such as guidance and investigation, the prejudiced approach of teachers to supervision, the lack of an explicit and constructive communication between teachers and supervisors, the insufficient number of the supervisors, having to much work load, not having educate time for the supervision and counseling can be sort as certain problems come up from the researches (Arabacl, 1995; Arslantaş, 2007; Atay, 1995; Aydın, 1993; Balaban, 2005; Balcı, Aydın, Yılmaz, Memduhoğlu \& Apaydın, 2007; Burgaz 1995; Büyükışık, 1989; Can, 2004; Ciğer, 2006; Dağlı, 2004; Doğanay, 2006; Döngel, 2006; Dündar, 2005; Ecevit 1996; Eyi, 2007; Gülcan, 2003; Gündüz, 2008; Illğan, 2006; Kapusuzoğlu, 1988; Karakış, 2007; Kartal 1997; Kavas, 2005; Korkmaz, 2007; Koruç, 2005; Memduhoğlu, Aydın, Yılmaz, Güngör \& Oğuz, 2007; Memduhoğlu \& Zengin, 2010; Memduhoğlu \& Zengin, 2012; Memişoğlu, 2001; Olgun, 2005; Pınardağ, 2005; Sabancı \& Günbayı, 2004; Sarı, 1987; Şahin, 2005; Taşar, 2000; Taymaz, 2002, Tok, 2004; Uyanık, 2007; Uygur, 2006; Ünal, 1999; Yavuz, 1995; Yıldırım, 2007).

Nowadays in the contemporary education perception, education supervisors are charged with the leading role to increase the quality of education at school and teachers and students learning (Sergiovanni \& Starratt, 2002; Kowalski \& Brunner, 2005; Nelson \& Sassi, 2000; Swaffield \& MacBeath, 2005; Weiss \& Weiss, 2001; Zepeda, 2001, 2002). In Turkey the existing supervision model considered as

* Corresponding author: hasanmemduhoglu@gmail.com 
a troubled field that cannot meet the need, it is emphasized in this field radical and totalitarian reorganization is required and it should be reconstructed. In this point it is seen a large study oriented of reconstruction of the structure and process dimensions of education supervision is necessary. Moving from this necessity troubles from supervision system, considering the circumstances and contemporary education perception of Turkey, a new education supervision model focused on developing counseling and education process has been improved

As seen in organization schema in Figure1, the new education supervision model providing supervision system integration is coordinated by Counseling and Supervision Presidency whose counseling and supervision activities are directly attached to the ministry. Within the Counseling and Supervision Presidency, central education supervisors department exists in the ministry central organization and local education supervisors department exists in the country organization. There are counseling and supervision groups and investigation and inquiry groups within local education supervisors department. This model suggests single supervision system that can be coordinated by one unit instead of dual supervision system. In country organization provides supervision to be done in local level and allows supervision groups based on proficiency/branch.

The aim of this study is to develop a model for the sub-system of education supervision in Turkey and to put forth how the developed model is adopted and applicable by the education supervisors. In the study to reach this general aim the answers for the questions below are sought.

1. What level the education supervisors adopt and find applicable the new developed education supervision model?

2. Does the adaptation and finding applicable level of the new education supervision model that put forward for the education supervisors show changes according to their degree, total working period and the region they are working?

\section{Method}

\section{Research Design}

The study is in the descriptive scanning model aimed to determine education supervisors ideas about developed education supervision sub system model. In the study mixed method that consists of quantitative and qualitative methods is used.

\section{Participants}

3083 education supervisors over Turkey create the universe of the study (MEB 2009f). The sample of the present study is composed of 555 education supervisors selected in two provinces of each geographic region. The sample is stated with the luminal sampling technique. According to this State Planning Organization (DPT), basing on the socio-economic development index of the provinces (Dinçer \& Özaslan, 2004), a developed and ever-developing province determined randomly in each region. 85\% of supervisors included in the sampling have an over 20 years length of service.

\section{Instrument}

Semi-structured interview form is used as the data collection instrument. Interview questions are the data of the study is gathered by the "Education Supervision Model Scale [Eğitim Denetimi Modeli Ölçeği (EDMÖ)] reflecting the basics education supervision model that has been developed by the surveyors and individual interviews. The validation and reliability analysis of the scale, whose primary practice is done on the 117 education supervisors from Van, Kahramanmaraş and Malatya provinces, is done. The 
scale is 46 items and five rating participation scale, and structured open ended question form is used in the interviews.

\section{Data Analysis}

The gathered original data during the study are analyzed with the descriptive (frequency, percentage and arithmetic average) and parametric tests. Also the opinions in the asked structured open ended questions are analyzed with the content analysis.

\section{Results}

According to research results, some themes including activity, time, student, preparation for other The education supervisors those participate the study had "wholly" adopted the structural dimension that reflects the organization structure and the process dimension that reflects the operation and had found out that both the structure and operation dimensions can "wholly" be executable in Turkish Education System.

\section{Discussion, Conclusion \& Implementation}

The wholly adapting of the structure dimension of the model by the supervisors and finding it executable in Turkish Education System, shows that the model is suitable for the circumstances of Turkey, realistic and offers a structure oriented to the necessity. The model suggesting a mono supervision structure that coordinated by one unit instead of a dual supervision structure and the ministry providing local level structuring and allowing supervision groups based on proficiency/branch, have the effect on the adoption and applicable level to be so high can be said.

According to the other symptoms came up education supervisors think that the model developed for the supervisor assistants can be more applicable in Turkish Education System. As educations supervisors vocational seniority rise the education supervisors' opinions concerning the reformed model can be applicable in Turkish Education System grow positively. The education supervisors working in Central Anatolia Region have adopted the suggested model less than the supervisors working in other regions. The supervisors working in Southeast Anatolia and East Anatolia Regions have found it less applicable as well.

As a result the problems in the supervision system, considering the circumstances of Turkey and contemporary education conception the new reformed education supervision model focused on developing counseling and education process has the potential to provide significant contributions to Turkish Education System. It is thought to be a model that the decision makers can benefit from while doing regulations and performers can benefit from in their practice. The education supervisors in Turkey fully adopting the new model and finding it applicable in Turkey can be accepted as an indicator. On this point doing surveys about the education supervision sub system structural problems and concerned with the process, getting the opinions of the participants such as ministry supervisors who refused to participate this study at first, teachers, education supervisors, the administrators in ministry and principals, using quantitative and qualitative methods together will be useful. 
Pegem Journal of Education \& Instruction, 4(2), 2014, 25-44

Pegem Eğitim ve Öğretim Dergisi, 4(2), 2014, 25-44

www.pegegog.net

\title{
Türkiye'de Eğitim Denetimi Alt Sisteminin Yeniden Yapılandırılmasına ìlişkin Bir Model Önerisi
}

\author{
Hasan Basri MEMDUHOĞLU ${ }^{\mathrm{a}^{*}}$, Abdulhakim TAYMUR ${ }^{\mathrm{b}}$ \\ ${ }^{a}$ Yüzüncü Yıl Üniversitesi, Eğitim Fakültesi, Van/Türkiye \\ ${ }^{\mathrm{b}}$ Eğitim Denetmenleri Başkanlığı, Van/Türkiye
}

\begin{tabular}{|c|c|}
\hline Makale B & \\
\hline DOI: 10.145 & egegog. 2014.008 \\
\hline Makale ges & \\
\hline Geliş & 18 Eylül 2013 \\
\hline Düzeltme & 02 Ocak 2014 \\
\hline Kabul & 03 Şubat 2014 \\
\hline Anahtar kel & \\
\hline $\begin{array}{l}\text { Denetim, } \\
\text { Eğitim dene } \\
\text { Denetim m }\end{array}$ & \\
\hline
\end{tabular}

\section{Öz}

\begin{abstract}
Bu araştırmanın amacı, Türkiye'de eğitim denetimi alt sistemi için bir model geliştirmek ve geliştirilen modelin eğitim denetmenleri tarafından ne düzeyde benimsendiğini ve uygulanabilir bulunduğunu ortaya koymaktır. Nitel ve nicel yöntemlerin birlikte kullanıldığı araştırmanın evrenini Türkiye genelinde görev yapan eğitim denetmenleri oluşturmaktadır. Araştırmanın örneklemi, her coğrafi bölgeden seçilen ikişer ilde görev yapan 555 eğitim denetmeninden oluşmaktadır. Araştırma kapsamında Türkiye'de eğitim denetimi alt sistemi için bir model geliştirilmiş ve bu model eğitim denetmenlerinin görüşüne sunulmuştur. Araştırmada eğitim denetmenlerinin önerilen modeli Türk eğitim sistemi için "tamamen" benimsedikleri ve uygulanabilir buldukları sonucuna ulaşılmıştır.
\end{abstract}

Giriş

Türkiye' de çok tartışılan, sürekli eleştirilen bazı konular vardır. Eğitim bunların başında gelmektedir. Eğitim konusundaki eleştirel tartışmalar eğitim ile ilgili herhangi bir platformda, bir toplantıda, bilimsel bir kongrede yapıldığı gibi, evde, okulda, işte, kahvede, sokakta da vatandaşlar arasında eğitim hep eleştirel tartışmalarla gündeme gelir. Eğitim denetimi de, tıpkı eğitim gibi her gündeme geldiğinde daha çok olumsuz yönleriyle konuşulur. Denetmenlerin tutumu, öğretmenlerin denetime soğuk bakışı, denetimin bir-iki ders saatinde geçiştirilerek yapıldığı, daha çok evrak ve dosyalara göre değerlendirme yapıldığı, denetimde verilen puanlardaki haksızlıklar, denetimin öğretmenleri geliştirmediği gibi birçok şikâyetten dem vurulur. Ancak denetimle ilgili bu tartışmalar, eğitimden farklı olarak halk arasında değil, daha çok öğretmenler, yöneticiler, denetmenler gibi eğitimin paydaşları arasında yapılmaktadır.

Eğitim denetiminin çoğunlukla olumsuz yanlarıyla gündeme gelmesi, denetim sisteminde bir şeylerin yanlış gittiği, sistemde bazı aksaklıklar olduğu düşüncesini gündeme getirir. $O$ halde gelişmiş ülkelerin uyguladığı çağdaş denetim anlayışını yansıtan düzenlemelere ihtiyaç olduğu söylenebilir. Türkiye'de toplumsal yaşamı eğitim yoluyla düzenleme ve denetleme arzusunun sonucu olarak eğitim denetimi, uzun yıllar boyunca kontrol, hata arama, öğretmenlerin hatalı davranmamaları için onları "teftiş" etme ve değerlendirme anlayışıyla uygulanmıştır. Günümüzde ise öğretim-öğrenme sürecini geliştirme ve rehberliği esas alan anlayışa dayalı dünyadaki uygulamalara paralel olarak bu hizmetin yürütülmesi gerektiği teorik olarak kabul görmektedir. Bu çağdaş denetim anlayışında eğitim denetmenlerine; okulda eğitimin ve öğretimin kalitesini artıran, öğretmeni ve öğrencilerin öğrenmesini geliştiren liderlik rolü yüklenmiştir (Kowalski ve Brunner, 2005; Nelson ve Sassi, 2000; Sergiovanni ve Starratt, 2002; Swaffield ve MacBeath, 2005; Weiss ve Weiss, 2001; Zepeda, 2001, 2002).

*Yazar: hasanmemduhoglu@gmail.com 
Eğitimde süreci geliştirme amaçlı denetimin gerekliliği konusunda görüş birliği olmakla birlikte (Kimbrough ve Burkett, 1990; akt. Aydın, 2005; Balcı, Aydın, Yılmaz, Memduhoğlu ve Apaydın, 2007; Başar; 2000; Memduhoğlu ve Zengin, 2010; Taymaz, 2005), Türkiye'de eğitim denetimi, sorunlu bir alan olarak değerlendirilmekte, bu alanda köklü ve bütüncül düzenlemelere gereksinim olduğu belirtilmektedir. Bundan dolayı sistemin sadece belli yanlarını dikkate alan sınırlı, geçici, palyatif çözümler yerine daha bütüncül ve kalıcı yeni modellerin ortaya konması gerekmektedir. Bu ihtiyaçtan hareketle denetim sisteminde yaşanan sorunlar, Türkiye'nin koşulları ve çağdaş eğitim anlayışı göz önünde bulundurularak, rehberlik ve eğitim sürecini geliştirme odaklı yeni bir eğitim denetimi modeli geliştirilmiştir.

\section{Türkiye'de Eğitim Denetiminde Yeni Model İhtiyacı}

Türkiye'de eğitim denetimi ile ilgili yapılan araştırmaların büyük çoğunluğu, sistemde önemli sorunların yaşandığı, denetim sürecinin amaca uygun işlemediği, denetimin öğretim sürecini ve öğretmenlerin mesleki becerilerini geliştirmekten uzak olduğu ve denetçilerin kendilerinden beklenen görevleri yeterince yerine getiremedikleri sonuçlarını ortaya koymaktadır. Literatürde yar alan çok sayıdaki bu araştırmalarda ulaşılan bulgulara dayalı olarak ön plana çıkan temel sorunlar; eğitim denetiminin yapılanması ve modeli, eğitim denetimine yüklenen anlam ve denetimden beklentilerin çağcıl olmaması, denetmenlerin rehberlik ve soruşturma gibi çelişen görev ve rolleri, denetmenlerin sayıca yetersiz ama işyüklerinin fazla olması, denetimlerin kontrol odaklı ve sınırlı zamanda yapılması gibi konulara odaklanmaktadır.

$\mathrm{Bu}$ araştırmaların çoğu, eğitim denetiminde model, yapı ve örgütlenme sorunsalını ön plana çıkarmaktadır. Özellikle bakanlık müfettişleri ve eğitim denetmenleri şeklindeki ikili yapının olumsuz sonuçlarına vurgu yapan çok sayıda araştırma mevcuttur (Arabacı, 1995; Arslantaş, 2007; Balaban, 2005; Ciğer, 2006; Doğanay, 2006; Döngel, 2006; Dündar, 2005; Gülcan, 2003; illğan, 2006; Kapusuzoğlu, 2008; Karakış, 2007; Kavas, 2005; Korkmaz, 2007; Koruç, 2005; Memduhoğlu, Aydın, Yılmaz, Güngör ve Oğuz, 2007; Memişoğlu, 2001; Olgun, 2005; Şahin, 2005; Taşar, 2000; Uyanık, 2007; Uygur, 2006; Ünal, 1999; Yavuz, 1995; Yıldırım, 2007). İki denetim birimi arasında organik bir bütünlük ve işbirliği bulunmamasının, öğretmenlere mesleki yardımı ve öğretimi geliştirmeyi esas alan denetim anlayışını olumsuz etkilediği (Memduhoğlu vd., 2007), bakanlık müfettişlerinin genellikle işletme anlayışına dayalı kurum denetimi yapmaya yoğunlaşmalarının, öğretim sürecini geliştirmeye yönelik rehberliğe ve mesleki gelişime öncelik veren denetim anlayışıyla örtüşmediği (Balcı vd. 2007; Eyi, 2007), ayrıca sürekli sahada (sınıf, okul) bulunması gereken bakanlık müfettişlerinin merkezde bulunmalarının, sürekli rehberlik ve denetimi olumsuz etkilediği vurgulanmaktadır. Nitekim bakanlık denetmenlerinin görev alanına giren ortaöğretim kurumlarında ders denetiminde sürekliliğin sağlanamadığı, uzun yıllar ders denetimi görmeyen ve rehberlik almayan öğretmenlerin çoğunlukta olduğu belirtilmektedir (Taymaz, 2002). Bu ikili yapının, eğitim denetimini yürüten birimler arasında eşgüdümü zorlaştırdı̆̆ı, görev çatışması ve sorumluluk binişmesine (Balcı vd., 2007) ve eğitim denetmenleri arasında huzursuzluğa neden olduğu vurgulanmaktadır (Tok, 2004, Pınardağ, 2005). Başaran (2004), denetim sisteminin artık eskisi gibi olamayacağını, mutlaka yeniden yapılandırılması gerektiğini belirtmektedir.

Araştırmalara eğitim denetmenlerinin illerde milli eğitim müdürlerine bağlı olarak görev yapmalarının önemli sorunlar yarattığını ortaya koymuştur (Balcı vd. 2007; Dağlı, 2004; Gündüz, 2008). il milli eğitim müdürü, eğitim denetmenlerinin disiplin ve idari amiridir. Ödüllendirilmeleri, cezalandırılmaları ve mesleki kariyerleri önemli ölçüde milli eğitim müdürlerine bağı olan eğitim denetmenlerinin, milli eğitim müdürünün yetki ve sorumlu alanına giren okul ve kurumlardaki yanlış uygulamaları nesnel biçimde raporlamaları milli eğitim müdürü ve dolayısıyla kendileri açısından bazı riskler taşır. Bu nedenle milli eğitim müdürlerine bağlı olarak görev yapmak, eğitim denetmenlerinin işlerini güçleştirmekte, bağımsız ve objektif hareket etmelerini olumsuz etkilemektedir (Balcı vd., 2007). iller bazında örgütlenmeden kaynaklanan birden fazla amire bağlı olmanın, yönetim birliği ilkesine aykırı olarak denetimin etkililik ve verimliliğini azalttığı belirtilmektedir (Taymaz, 2002). Ayrıca eğitim denetmenlerinin bir il düzeyinde 
görev yapmaları, özellikle küçük illerde bazı sorunlar yaratır. Denetmen ne kadar uzaktan olursa ve değerlendirme ne kadar uzaktan yapılırsa, kişisel yaşamın ve duyguların değerlendirmeye etkisi o derece azalabilmektedir (Aydın, 1993). Dağlı’nın (2004) yaptığı araştırmada, eğitim denetmenlerinin kendilerini en çok zorlayan sorunların sırasıyla İ Milli Eğitim müdürlüklerine bağı olmaları, kendilerine verilen soruşturma görevi ve yoğun iş yükü olduğu ortaya çıkmıştır. Gündüz'ün (2008) araştırmasında da, denetçilerin denetim sisteminin merkezi ve bölgesel düzeyde örgütlenmesi görüşünü taşıdıkları ve bu konuda yenilenme ihtiyacı bulunduğu sonucuna ulaşılmıştır.

Araştırmalarla ortaya konan diğer bir sorun, rehberlik, yardım ve geliştirme esaslı denetim yerine kontrol odaklı biçimsel denetimin yapılmasıdır (Can, 2004; Memduhoğlu ve Zengin, 2012; Sabancı ve Günbayı, 2004). Bu sorun, esasında eğitim denetimine yüklenen anlam ve eğitim denetiminden beklentilerin çağa uygun olmamasından kaynaklanır. Esasında Türkiye'de toplumu dönüştürme, yeni bir toplum yaratma projesi olan Cumhuriyetin ilanından itibaren toplumsal dönüşümün başat aygıtı olarak görülen eğitime özel anlamlar yüklenmiş, bu dönüşüm hedefinin sonucu olarak üzerinde özenle durulan eğitimin denetimi de uzun yıllar eğitim uygulamalarını kontrol altında tutma anlayışıyla yürütülmüştür. Türkiye'de görece uzun bir geçmişi olan eğitim denetimine ilişkin zengin literatürde de bu sürecin çoğunlukla kontrol, hata arama ve değerlendirme anlayışıyla yürütüldüğüne ilişkin eleştirilerin fazlalığı dikkat çekmektedir. Memduhoğlu'nun (2009) yaptığı araştırmada öğretmen ve yöneticilerin, denetimde daha çok evrak denetiminin yapıldığı, öğretmenlerin sınıf içi öğretim eksikliklerinin belirlenip giderilmesine ve mesleki gelişimlerine pek odaklanılmadığı, ancak bu anlayışın son dönemlerde kısmen değiştiği görüşünde oldukları ortaya konmuştur. Burgaz (1995), denetmenin değerlendirme ve rehberlik rollerinde olduğu gibi öğreticilik rolüne ilişkin olarak birtakım yetersizliklerinin de olduğunu belirtmektedir. Balcı ve diğerlerine (2007) göre, kontrol odaklı denetim, denetleneni savunmaya, eksik ve yanlışlarını gizlemeye yöneltir. Sistemdeki en yetkin kişi olması gereken denetmenin, sistemdeki eksik ve yanlışları raporlayıp bırakması, bunların düzeltilip geliştirilmesine yönelmemesi, çağdaş denetimin geliştirici işlevine aykırı düşmektedir.

Yapılan araştırmalar rehberlik ve soruşturma gibi birbirinden çok farklı ve çelişkili rollerin denetmenlere verilmesinin, onlardan beklenen rehberlik ve yardım rolünü gereği gibi yerine getirmelerini zorlaştırdığını ortaya çıkarmıştır (Atay, 1995; Can, 2004; Dağlı, 2004; Kapusuzoğlu, 2008; Memduhoğlu vd., 2007; Memduhoğlu ve Zengin, 2010). Rehberliğin ve yardımın özünde gönüllülük yatar. Hem yardım edenin hem de yardım alanın buna hazır olması ve birbirine güven duyması gerekir. Kurala aykırı bir davranış sergilemesi durumunda denetmen tarafından soruşturmaya tabi tutulacağını bilen bir öğretmenin, aynı denetmenden rehberlik ve yardım almaya istekli ve hazır olmasını ve bunu alırken rahat davranmasını beklemek gerçekçi olmaz. Bu durum denetmenlerin rehberlik ve mesleki yardım görevlerini yerine getirmelerini zorlaştırmaktadır (Dağlı, 2004; Gündüz, 2008). Ayrıca denetmenler ile öğretmenler arasında açık ve sağııkı bir iletişimin olmadığı, bunun nedenleri arasında denetime ilişkin olumsuz algının, denetmenlerin yaklaşımlarının ve denetmenlerin üstlendikleri soruşturma görevinin etkili olduğu belirtilmektedir (Büyükışık 1989; Ecevit 1996; Kartal 1997; Sarı, 1987; Memişoğlu, 2001; Ünal, 1999).

Eğitim denetmenleri hem sınıf hem de branş öğretmenlerini denetlemektedir. Ancak her ilde her branştan yeterli sayıda denetmen bulunmaması, denetmenlerin bazen uzmanı olmadığı bir alanda branş öğretmenlerini denetlemesini gerektirmektedir. Bu durumda denetmenin öğretmene yeterli rehberlik ve danışmanlık yapması zorlaşmaktadır.

Pek çok araştırmada denetmenlerin sayılarının yetersiz, işyüklerinin ağır olduğu sonucuna ulaşılmıştır (Arabacı, 1995; Can, 2004; Dağlı, 2004; Kapusuzoğlu, 2008; Memişoğlu, 2001; Ünal, 1999). Bundan dolayı rehberliğe yeterince zaman ayrılmamakta, denetimler çoğu zaman bir-iki ders saatlik sınırlı bir zaman diliminde geçiştirilmektedir (Sabancı ve Günbayı, 2004).

Çeşitli tarihlerde yapılan milli eğitim şuralarında da eğitim denetiminin sorunlarına yer verilmiş ve bu sorunların çözümüne yönelik tavsiye kararları alınmıştır. On birinci milli eğitim şurasında bakanlık ve ilköğretim müfettişliği ayırımı yerine "eğitim müfettişi” kavramı ilk kez kullanılmış, eğitim müfettişliği 
uzmanlık alanı olarak benimsenmiştir (MEB, 2008a). On ikinci milli eğitim şurasında denetmenlerin yetiştirilmesine özel vurgu yapılmıştır (MEB, 2008b). On dördüncü ve on beşinci milli eğitim şuralarında denetmenlerin lisansüstü düzeyde yetiştirilmeleri, denetimde rehberliğin ön plana çıkarılması, denetim sisteminin yeniden ele alınarak bakanlık ve ilköğretim müfettişliğinin bir çatı altında birleştirilmesi gerektiği belirtilmiştir (MEB, 2008c,d). On yedinci milli eğitim şurasında; ilköğretim müfettişliğinin, "eğitim müfettişliği" adı altında bakanlık merkez örgütüne bağlanarak yeniden yapılandırılması, denetim yapılanmasında bölge sistemine geçilmesi ve eğitim müfettişlerinin yeni oluşturulacak çalışma merkezlerinde/bölgelerinde görevlendirilmesi, eğitim müfettişlerinin kendi içerisinde rehberlik ve denetim, soruşturma, okul öncesi ve özel eğitim gibi alanlarda uzmanlaşmaları, tüm eğitim kademelerinde niteliğin belli standartlara göre denetlenmesini sağlamak amacıyla niteliği değerlendirme (akreditasyon) çalışmalarının yapılması, merkez teşkilatının süreç odaklı olarak yeniden yapılandırılması tavsiye edilmiştir.

Yukarıda açıklandığı gibi milli eğitim şuralarında mevcut denetim alt sisteminin yeniden yapılandırılması gerektiğine kuvvetli bir vurgu yapılmakta, özellikle On yedinci milli eğitim şurasında denetim sistemine ilişkin köklü değişiklikler önerilmektedir (MEB, 2008e). Şuralarda yeniden yapılandırma için önerilen modelde, bakanlık merkez ve taşra teşkilatının yapı boyutunun değişmesi gerektiği, denetimdeki iki başlı yapıya son verilerek "eğitim müfettişliği” adı altında tek bir yapının kurulması, müfettişlerin lisansüstü eğitimden geçirilmeleri, müfettişlerin görev tanımlarının yeniden yapılarak denetimin daha etkili bir yapıya kavuşturulması gerektiği ortaya konmuştur.

Gerek Türk eğitim sistemi denetim alt sistemi ile ilgili yapılan araştırmalarda ve gerekse milli eğitim şuralarında alınan kararlarda mevcut denetim modelinin ihtiyaca cevap veremediği ve yeniden yapılanması gerektiği vurgulanmaktadır. Ancak, konu ile ilgili literatür incelendiğinde, denetim sistemi ile ilgili getirilen önerilerin bütünleştirilerek bir model olarak ortaya konduğu bir çalışmaya rastlanmamıştır. Bu konuda eğitim denetimi alt sisteminin yapı ve süreç boyutlarının yeniden yapılandırılmasına yönelik kapsamlı bir çalışmaya ihtiyaç duyulduğu görülmektedir. Bu ihtiyaçtan hareketle, bu çalışmada, konu ile ilgili mevcut literatür, yapılan araştırmaların sonuçları ve milli eğitim şuralarında alınan kararlar, sistematik bir şekilde ve bir bütün olarak ele alınarak modelleştirilmiş ve böylece Türk eğitim sistemi için yeni bir denetim alt sistemi modeli ortaya konmuştur. Aşağıda geliştirilen bu model hakkında ayrıntılı bilgiye yer verilmiştir. İkinci aşamada eğitim denetimi alt sisteminin en önemli paydaşları konumunda olan denetmenlerin geliştirilen bu yeni denetim modelini ne ölçüde benimsedikleri ve modeli hangi düzeyde uygulanabilir buldukları belirlenmeye çalışılmıştır.

\section{Türk Eğitim Sitemi Denetim Alt Sistemi İçin Önerilen Yeni Model}

Türkiye'de eğitim denetimi alt sisteminin amaç, yapı, süreç ve işleyiş boyutlarının yeniden yapılandırılmasına yönelik, mevcut literatür, yapılan araştırmalar ve milli eğitim şuralarında alınan kararlar sistematik ve bütüncül bir şekilde değerlendirilerek geliştirilen öneriler ve alınan kararlar doğrultusunda yeni bir denetim alt sistemi modeli ortaya konmuştur. Ayrıca on beş ilköğretim müfettişi ile görüşmeler yapılmış ve modelin geliştirilmesinde bu görüşlerden de yararlanılmıştır. Türk eğitim sitemi için geliştirilen ve önerilen yeni denetim modelinin örgüt yapısı şekil 1'de gösterilmiştir.

Şekil 1'deki örgüt şemasında görüldüğü gibi, denetim sistemini bütünleştirmeyi öngören yeni eğitim denetimi modelinde, rehberlik ve denetim faaliyetleri doğrudan bakanlığa bağı olan Rehberlik ve Denetim Başkanlığı tarafından koordine edilmektedir. Rehberlik ve Denetim Başkanlığı bünyesinde bakanlık merkez örgütünde merkez eğitim müfettişleri, taşra teşkilatında ise bölge eğitim müfettişleri başkanlıkları bulunmaktadır. Bölge eğitim müfettişleri başkanlığı bünyesinde rehberlik ve denetim grupları ile inceleme ve soruşturma grupları yer almaktadır. Aşağıda yeni denetim modelinin yapısı ve işleyişi ayrıntılı olarak açıklanmıştır. 


\section{Rehberlik ve denetim başkanlığı}

Milli Eğitim Bakanlığının bütün rehberlik, denetim ve soruşturma faaliyetleri Rehberlik ve Denetim Başkanlığının koordinasyonunda yürütülecektir. Böylelikle, denetim alt sisteminin bütünleştirilmesi sağlanmaktadır. Rehberlik ve Denetim Başkanlığı; başkan, başkan yardımcıları, merkez eğitim denetmenleri, eğitim denetmenleri, Araştırma Geliştirme (AR-GE) Komisyonu ve büro personelinden oluşmaktadır.

Rehberlik ve Denetim Başkanlığı'na, bakanlık merkez eğitim başdenetmenleri arasından en az on iki yıl denetmenliği bulunanlardan, başkan yardımcılığına merkez eğitim başdenetmenleri arasından en az beş yıl denetmenliği bulunanlardan mesleki yetenek, başarı ve kıdem durumları birlikte değerlendirilmek suretiyle atama yapılır. Başkan; görevlerini bakan adına yürütür. Başkan, yıllık rehberlik ve denetim programını hazırlayıp bakanın onayından sonra uygulanmasını sağlar. Denetmenlerin hizmet içi eğitimleri ve denetmen yardımcılarının yetişmelerine yönelik önlemler alır.

\section{Merkez eğitim denetmenleri}

Önerilen modele göre halen görev yapan bakanlık müfettişleri, merkez eğitim denetmeni olarak Rehberlik ve Denetim Başkanlığı bünyesinde görev yapacaktır. Eğitim denetmen yardımcılığı, eğitim denetmenliği ve eğitim başdenetmenliği unvan sistemi bulunmaktadır. Buna göre, üç yıl merkez eğitim denetmen yardımcılığı süresi sonunda yapılan yazılı yeterlilik sınavı ve mülakat sonucunda başarılı olan denetmen yardımcıları, merkez eğitim denetmenliği kadrolarına atanırlar. Beş yılık merkez eğitim denetmenliği görevini tamamlayan denetmenler, merkez eğitim başdenetmenliği kadrolarına atanırlar. Merkez eğitim denetmenleri, il/ilçe milli eğitim müdürlükleri ile bakanlık merkez örgütünde denetim yaparlar. Ayrıca Bakanlığı ilgilendiren konularda yurt içinde ve dışında inceleme ve araştırmalar yapar, görevlendirildikleri komisyon, seminer, toplantı ve benzeri mesleki çalışmalara katılırlar. Merkez eğitim denetmenliğine, on yıllık denetmenlik kıdemi olan bölge eğitim denetmenleri arasından atama yapılır.

\section{Eğitim denetimi araştırma geliştirme (Ar-Ge) komisyonu}

Rehberlik ve Denetim Başkanlığı bünyesindeki bu komisyonda, her branştan yeterli sayıda eğitim denetmeni görev yapar. Komisyon üyeleri, en az beş yıl deneyimi olan eğitim denetmenleri arasından Başkanın önerisi ve bakanın onayı ile bir yıllığına görevlendirilirler. Komisyon her yıl rehberlik, denetim ve soruşturma rehberlerini hazırlar, rehberlik ve denetimde kullanılacak formları hazırlar ve günceller.

\section{Bölge eğitim denetmenleri başkanlığı}

Önerilen yeni modele göre eğitim denetiminde bölge yapılanmasına gidilmektedir. Milli Eğitim Bakanlığı'nın taşra teşkilatında bulunan eğitim kurumlarının her türlü faaliyet ve işlemleriyle ilgili olarak rehberlik, denetim, inceleme ve soruşturma işleri bölge eğitim denetmenleri başkanlıkları tarafından yürütülecektir. Türkiye genelinde, 15 bölgede eğitim denetmenleri başkanlığı kurulur. Her eğitim denetimi bölgesi coğrafi olarak yakın 5-6 ilden oluşur. Bölge eğitim denetmenleri başkanlıkları, ulaşım ve sosyo-ekonomik özellikler bakımdan bölgede merkez konumunda bulunan illerde kurulur.

Bölge eğitim denetmenleri başkanlığı için, en az on yıl denetmenlik deneyimine sahip adaylar arasında bölge eğitim denetmenlerinin oy kullandığı seçim yapılır, seçimde en çok oy alan iki adaydan biri rehberlik ve denetim başkanının teklifi ve milli eğitim bakanının onayı ile başkan olarak atanır. Başkanın görev süresi üç yıldır ve aynı kişi en fazla iki dönem başkanlık yapabilir. Her bölgede, bağlı il sayısı kadar bölge eğitim denetmenleri başkan yardımcısı görevlendirilir. Büyük şehirlerde her 50 denetmen için bir başkan yardımcısı görevlendirilir. Başkan yardımcıları, en az beş yıl denetmenlik kıdemi olanlar arasından, bölge eğitim denetmenleri başkanının teklifi, rehberlik ve denetim başkanının onayı ile üç yıllığına atanır. 


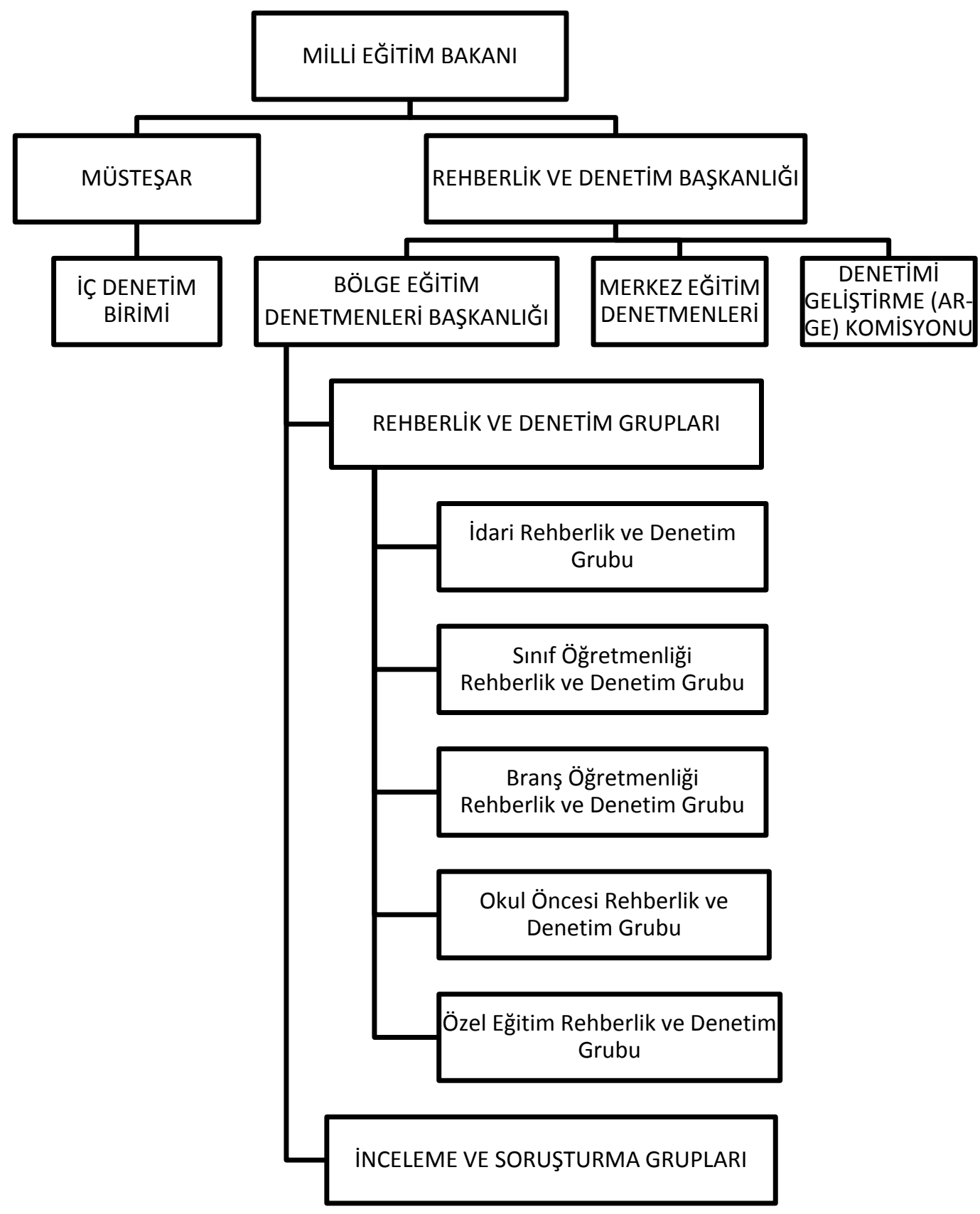

Şekil 1. Türk Eğitim Sitemi İ̧̧in Geliştirilen Denetim Modeli.

Bölge başkanlıkları bünyesinde rehberlik ve denetim grupları ile inceleme ve soruşturma grupları oluşturulur. Böylelikle rehberlik ve soruşturma görevleri birbirinden ayrılarak farklı gruplarca yürütülmesi sağlanmıs olacaktır. Rehberlik ve denetim grupları, uzmanlık alanlarına göre şöyle oluşturulur:

- Idari rehberlik ve denetim grubu,

- Sınıf öğretmenliği rehberlik ve denetim grubu,

- Branş öğretmenliği rehberlik ve denetim grubu,

- Okul öncesi rehberlik ve denetim grubu,

- Özel eğitim rehberlik ve denetim grubu. 
Rehberlik ve denetim gruplarının sorumlu bulunduğu iller/kurumlar her yıl değiştirilerek eğitim denetmenlerinin bölgeye bağlı farklı illerde çalışması sağlanır. Eğitim denetmenleri, bölge başkanlığının bulunduğu ilde ikamet ederler. Uzmanlık alanlarına göre oluşturulan gruplar turne usulü ile illere giderek çalışırlar. İnceleme ve soruşturma grupları, bölgeye bağlı illerdeki eğitim kurumlarında her türlü inceleme ve soruşturma işlerini yürütürler. Bu gruplardaki denetmenler, eğitim denetmenleri arasından gönüllük esasına göre en az beş yıllığına atanır.

\section{Eğitim denetmenlerinin seçilme ve atanma usulleri ve çalışma esasları}

Bölge eğitim denetmen yardımcılığına sınavla atama yapılır. Sınava başvurabilmek için şu şartlar aranır:

- Eğitim yönetimi ve denetimi alanında veya atanacağı branşı ile ilgili alanda lisansüstü eğitim yapmış olmak,

- Bakanlığa bağlı okullarda; branşında en az sekiz yıl öğretmenlik veya branşında dört yıl öğretmenlik yaptıktan sonra bakanlık teşkilatında veya okullarda en az üç yıl yöneticilik görevi yapmış olmak.

Sınav yazılı ve mülakattan oluşur. Eğitim denetmen yardımcılığı süresi üç yıldır. Bu süre sonunda yapılan yazılı yeterlilik sınavı ve mülakat sonucunda başarılı olanlar, eğitim denetmenliği kadrolarına atanırlar. Beş yılık eğitim denetmenliği görevini tamamlayanlar, bölge rehberlik ve denetim başkanının teklifi, rehberlik ve denetim başkanının önerisi ve bakanın onayı ile eğitim başdenetmenliğine atanırlar. Mevcut eğitim denetmenlerinin lisansüstü eğitimlerini tamamlayabilmeleri için Milli Eğitim Bakanlığı ve üniversiteler işbirliği yaparlar. Eğitim denetmenleri genel idare hizmetleri sınıfında yer alır.

Eğitim denetmenlerinin çalışma usul ve esasları aşağıdaki ilkelere dayanır:

- Resmi ve özel okulöncesi, ilköğretim ve ortaöğretim okulları ile tüm eğitim kurum ve kuruluşlarında denetim, rehberlik, inceleme ve soruşturma görevleri eğitim denetmenlerince yürütülür.

- Eğitim kurumlarında, eğitim-öğretim yılı birinci yarıyılında rehberlik ve seviye tespiti, ikinci yarıyılda ise başarı tespiti ve değerlendirme yapılır.

- Denetim faaliyetleri, Ar-Ge Komisyonu tarafından geliştirilen formlardaki kriterlere göre yapılır. Kriterler esnek-çerçeve özelliği taşır. Eğitim denetmeni, rehberlik ve denetim faaliyetlerinde bireysel farklılıkları ve çevresel koşulları dikkate alarak formlardaki kriterler dışındaki hususları değerlendirmede göz önünde bulundurabilir.

- Her eğitim denetmeni kendi branşında rehberlik ve denetim yapar. Rehberliğe daha çok ihtiyaç duyan kurumlar belirlenerek bunlara öncelik verilir.

- Bölge eğitim denetmenleri başkanlıklarının birer web sitesi bulunur. Eğitim denetmenleri, Ar-Ge Komisyonu tarafından geliştirilen e-rehberlik hizmeti sunarlar.

- Rehberlik ve denetim grupları, rehberlik ve mesleki yardıma öncelik verirler. Eğitim denetmenleri, rehberlik ve denetim sürecinde kurumdaki doğru uygulamaları yerleştirme ve yayma, sorunları belirleyerek öğretmen ve yöneticilerle birlikte düzeltici çözümler geliştirme, mesleki yardım ve iş başında yetiştirme ilklerini esas alırlar. Eğitim denetmenleri, rehberlik ve denetimini yaptığı kişi ile birlikte sorunları paylaşır, çözüm önerileri geliştirir ve gerekirse bir gelişim plânı hazırlayarak uygulamasını izlerler.

- Denetmenler, çalışmalarında güdülemeyi ve morali artırmayı, iş doyumu sağlamayı, üretim ve verimliliği en üst düzeye çıkarmayı ve öğretme-öğrenme sürecini geliştirmeyi, rehberlik ve denetim faaliyetlerini demokratik bir süreçte yapmaya, yetkiden çok etkiyi, özendirmeyi, ödülü, işbirliğini ve katılmayı esas alırlar.

- Eğitim denetmenlerine e-okul uygulamaları, iletişim ve insan ilişkileri, çağdaş denetim yaklaşımları gibi konularda periyodik hizmet içi eğitim verilir. Ayrıca denetmenlerin, yurt içinde ve yurt dışında mesleki inceleme ve araştırmalar yapmaları sağlanır. 
Amaç

Bu araştırmanın genel amacı; Türkiye'de eğitim denetimi için yeni bir model geliştirmek ve geliştirilen yeni modelin eğitim denetmenleri tarafından ne düzeyde benimsendiğini ve uygulanabilir bulunduğunu belirlemektir. Araştırmada bu genel amaca ulaşmak için aşağıdaki sorulara cevap aranmıştır.

1. Geliştirilen eğitim denetimi modelini, eğitim denetmenleri hangi düzeyde benimsemekte ve uygulanabilir bulmaktadırlar?

2. Eğitim denetmenlerinin önerilen eğitim denetimi modelini benimseme ve uygulanabilir bulma düzeyleri; unvana, toplam hizmet süresine ve görev yaptıkları bölgeye göre farklılık göstermekte midir?

\section{Yöntem}

\section{Araştırmanın Modeli, Evren ve Örneklemi}

Araştırma, geliştirilen eğitim denetimi alt sistemi modeline ilişkin eğitim denetmenlerinin görüşlerini belirlemeye yönelik betimsel tarama modelindedir. Tarama araştırmaları mevcut durumu ortaya koymayı amaçlar. Araştırmada nitel ve nicel yöntemlerden oluşan karma yöntem kullanılmıştır. Araştırmanın evrenini Türkiye çapında görev yapan 3083 eğitim denetmeni oluşturmaktadır (MEB, 2009f). Araştırmanın örneklemi ise Türkiye'nin yedi coğrafi bölgesindeki on dört ilde görevli 555 eğitim denetiminde oluşmaktadır. Örneklem tabakalı örnekleme tekniği ile belirlenmiştir. Buna göre örnekleme alınan eğitim denetmenlerinin görev yaptıkları iller coğrafi bölge esasına göre yedi tabakaya ayrılmıştır. Devlet Planlama Teşkilatının (DPT), illerin sosyo-ekonomik gelişmişlik endeksi esas alınarak (Dinçer ve Özaslan, 2004), her bölgeden bir gelişmiş bir de gelişmekte olan il seçkisiz olarak belirlenmiştir. Örnekleme alınan illerde görev yapan bütün eğitim denetmenleri örnekleme dahil edilmiştir. Buna göre örneklemi oluşturan 555 eğitim denetmenine gönderilen ölçme aracından 385'i geri dönmüş ve değerlendirmeye alınmıştır. Araştırmaya katılan denetmenlerinin bazı kişisel özellikleri Tablo $1^{\prime}$ de verilmiştir.

Tablo 1'de görüldüğü gibi araştırmaya katılan ve anketleri eksiksiz dolduran toplam 385 denetmenin sadece 10'u kadın, 375'i erkektir. Kadınların eğitim denetmeni ol(a)maması, toplumun sosyo-kültürel yapısı ve mesleğin koşulları ile açıklanabilir. \% 10'u eğitim denetmeni yardımcısı olan katılımcılardan lisansüstü eğitim mezunu olanların oranı \% 8'in altındadır. Denetmenlerin \% 85'inin mesleki kıdemi 20 yılın üzerindedir. Yarıya yakını da 30 yılın üzerinde mesleki deneyime sahiptirler. Bu durum eğitim denetmenliğinde mesleki deneyimin önemli olduğunu ortaya koymaktadır.

\section{Verilerin Toplanması}

Araştırma verileri, ölçek uygulaması ve bireysel görüşmelerle toplanmıştır. Bunun için "Eğitim Denetimi Modeli Ölçeği (EDMÖ)" ve yapılandırılmış açık uçlu soru formu kullanılmıştır. Araştırmada kullanılan ölçek ile ilgili aşağıda ayrıntılı bilgi verilmiştir.

\section{Veri toplama aracının geliştirilmesi}

Veri toplamada kullanılan ölçme aracını geliştirmek için, Türkiye'de eğitim denetimine yönelik mevcut literatür, araştırma sonuçları ve milli eğitim şuraları kararları doğrultusunda geliştirilen denetim modelinin temel özellikleri ifadeleştirilerek modeli yansıtan bir taslak form oluşturulmuştur. İkinci aşamada, anket taslağındaki maddelerden benzerlik taşıyanlar elenmiş ve sekiz alan uzmanının görüşüne sunulmuş, uzmanların önerileri doğrultusunda 57 maddelik taslak ön uygulamaya hazır hale getirilerek "Eğitim Denetimi Modeli Ölçeği (EDMÖ)" olarak adlandırılmıştır. Ölçekte, katılımcıların önerilen modeli benimseme düzeyleri ile Türk eğitim sisteminde ne ölçüde uygulanabilir bulduklarının saptanması 
amaçlanmıştır. Likert tipi beşli derecelendirme şeklinde oluşturulan ölçek, "hiç, az, orta, büyük ölçüde ve tamamen" katılım seçeneklerinden oluşmuştur.

Van, Kahramanmaraş ve Malatya illerinde görevli 117 eğitim denetmeni üzerinde ön uygulaması yapılan ölçeğin geçerlik ve güvenirlik analizleri yapılmıştır. Yapı geçerliliği için faktör analizi tekniği olan Temel Bileşenler Analizi kullanılmıştır. Güvenirlik çalışması için de Cronbach Alpha katsayısı hesaplanmıştır. Ayrıca her bir maddenin ayırt ediciliği için madde toplam korelasyonlarına bakılmıştır.

Tablo 1.

Araştırmaya Katılan Eğitim Denetmenlerine Ilişkin Bazı Demografik Özellikler.

\begin{tabular}{llrr}
\hline Değişken & Düzey & N & \% \\
\hline Görev & Eğitim denetmeni & 346 & 89.9 \\
& Eğitim den. yrd. & 39 & 10.1 \\
\hline Görev Yeri (il) & Antalya & 40 & 10.4 \\
& Osmaniye & 14 & 3.6 \\
& Erzurum & 36 & 9.4 \\
& Muş & 12 & 3.1 \\
& Denizli & 24 & 6.2 \\
& Muğla & 22 & 5.7 \\
& Gaziantep & 36 & 9.4 \\
& Siirt & 8 & 2.1 \\
& Kayseri & 46 & 11.9 \\
& Aksaray & 15 & 3.9 \\
& Samsun & 53 & 13.8 \\
& Bayburt & 4 & 1.0 \\
& Bursa & 62 & 16.1 \\
& Kırklareli & 13 & 3.4 \\
\hline Kadın & 10 & 2.6 \\
& Erkek & 375 & 97.4 \\
\hline Öğrenim Düzeyi & Lisans & 355 & 92.2 \\
& Lisansüstü & 30 & 7.8 \\
\hline Kıdem & $1-20$ yıl & 57 & 14.8 \\
& $21-30$ yıl & 151 & 39.2 \\
& 31 yıl ve üstü & 177 & 46.0 \\
\hline & & 385 & 100.0 \\
\hline
\end{tabular}

Verilerin analize uygunluğunu belirlemek için bakılan KMO değeri 0.817 bulunmuştur. Bu değer verilerin analizler için uygun olduğunu göstermektedir. KMO değerinin uygun olduğunun görülmesinin ardından veriler temel bileşenler analizine tabi tutulmuş ve yapılan analizler sonucunda, ölçeğin iki faktörlü çıktığı, bunun, ölçeğin hazırlanmasında öngörülen temel yapıları (yapı ve süreç) yansıttığı belirlenmiştir. Yapılan çalışmada her hangi bir maddenin ölçekte yer almasına karar verilirken faktör yük değerinin .45 ya da daha yüksek olmasının seçim için iyi bir ölçüt olacağı belirtilmiştir. Ancak uygulamada az sayıda madde için bu sınır değerinin .30'a kadar indirilebileceği ileri sürülmüştür. Öte yandan bir maddenin yüksek iki yük değeri arasındaki farkın en az .10 olmasına dikkat edilerek, çok faktörlü bir yapıda birden çok faktörde yüksek yük değeri veren madde, binişik bir madde olarak tanımlanmakta ve ölçekten çıkarılması gerektiği açıklanmaktadır (Büyüköztürk, 2002). Illk analizler sonucunda analize alınan maddelerden on biri yukarıda belirtilen ölçütleri karşılamadığından ölçekten çıkartılmıştır. Buna göre kalan 46 maddenin faktör yük değerlerinin .39 ve yukarısında olduğu ve ayrı faktörlerde yer aldığı görülmüştür. Yapılan döndürme sonucunda ölçekte yer alan maddelerin birbirinden bağımsız 2 faktörde toplandığı; maddelerin faktörlerindeki yük değerlerinin .387 ile .841 arasında değiştiği görülmüştür. Faktörlerde yer alan maddelerin madde toplam korelasyonları birinci faktörde .372 ile . 671, ikinci 
faktörde .313 ile .633 arasında değişmektedir. Her faktörün açıkladıkları varyans oranı sırasıyla, birinci faktörde \%20.988 ve ikinci faktörde \%22.866'dir. Her iki faktörün açıkladığı toplam varyansın ise \% 43.854'tür. Güvenirlik için hesaplanan Cronbah Alfa katsayısı birinci faktör için .924, ikinci faktör için 939 ve toplamda $.946^{\prime}$ olarak bulunmuştur. Diğer yandan ölçeğin iki faktörlü kullanımının yanı sıra, tek faktörlü kullanılabilirliğini değerlendirmek için ölçekte yer alan maddelerin açıkladığı varyans değerlerine bakılmıştır. Ölçeğin tek faktörlü olarak açıklanan varyans değeri \% 32,391 olarak tespit edilmiştir. Elde edilen bu değer ölçeğin tek faktörlü olarak kullanılmasını da olanaklı kılmaktadır. Ölçeğin birinci boyutunda (yapı) 25 ve ikinci boyutunda (süreç) 21 madde yer almıştır.

\section{Verilerin Çözümlenmesi}

Araştırmada uygulanan ölçek ile toplanan veriler, betimsel (frekans, yüzde, aritmetik ortalama) ve parametrik testlerle analiz edilmiştir. Ayrıca sorulan uçlu soruda belirtilen görüşler, kategorilendirilerek içerik analizi ile çözümlenmiştir.

\section{Bulgular}

Araştırma bulguları sırasıyla; "denetim modelinin benimsenme ve uygulanabilme düzeyine ilişkin bulgular", "kişisel değişkenlere ilişkin bulgular" ve "açık uçlu soruya ilişkin bulgular" başlıkları altında sunulmuştur.

\section{Eğitim Denetimi Modelinin Benimsenme ve Uygulanabilme Düzeyine iliş̧kin Bulgular}

Ölçeğin boyutlarına göre araştırmaya katılan eğitim denetmenlerin geliştirilen eğitim denetimi modelini benimseme ve uygulanabilme düzeyine ilişkin görüşlerinin aritmetik ortalama ve standart sapma değerleri Tablo 2'de verilmiştir.

\section{Tablo 2.}

Ölçeğin Boyutlarına Göre Eğitim Denetmenlerinin Geliştirilen Modeli Benimseme ve Uygulanabilme Düzeyine iliş̧kin Bulgular.

\begin{tabular}{llcc}
\hline Boyutlar & & $\overline{\boldsymbol{X}}$ & ss \\
\hline Yapı & Benimseme Düzeyi & 4.53 & 0.86 \\
& Uygulanabilme Düzeyi & 4.29 & 1.02 \\
\hline Süreç (işleyiş) & Benimseme Düzeyi & 4.70 & 1.04 \\
& Uygulanabilme Düzeyi & 4.34 & 0.91 \\
\hline
\end{tabular}

Tablo 2' de görüldüğü gibi araştırmaya katılan eğitim denetmenleri geliştirilen modelin yapı $(\overline{\mathrm{X}}=4.53)$ ve süreç ( $\bar{X}=4.70)$, boyutunu "tamamen" benimsemiş ve Türk eğitim sisteminde hem yapı ( $\bar{X}=4.29)$ hem de süreç ( $\overline{\mathrm{X}}=4.34)$ boyutunu "tamamen" uygulanabilir bulmuşlardır.

\section{Kişisel Değişkenlere iliş̧kin Bulgular}

Eğitim denetmenlerinin kişisel değişkenlerine göre geliştirilen modele ilişkin görüşlerini belirlemek için, verilerin normal dağılım göstermemesi nedeniyle parametrik olmayan testler yapılmıştır. Buna göre eğitim denetmenlerinin görüşlerinin unvan değişkenine göre değişip değişmediğini belirlemek için yapılan Mann Whitney U-testi sonuçları Tablo 3'te verilmiştir. 
Tablo 3.

Eğitim Denetmenlerin Önerilen Modele Ilişkin Görüşlerinin Unvan Değişkenine Göre Mann Whitney UTesti Sonuçları.

\begin{tabular}{llrrrrr}
\hline & Unvan & N & Sıra Ortalaması & Sıra Toplamı & U & P \\
\cline { 2 - 5 } Benimseme & Eğitim Denetmeni & 346 & 194.50 & 67298.0 & 6227.0 & .429 \\
& Eğitim Den. Yrd & 39 & 179.67 & 7007.0 & & \multirow{2}{*}{001} \\
\hline Uygulanabilir & Eğitim Denetmeni & 346 & 199.39 & 68989.0 & \multirow{2}{*}{4536.0} & .001 \\
Bulma & Eğitim Den. Yrd & 39 & 136.31 & 5316.0 & & \\
\hline
\end{tabular}

Tablo 3'te görüldüğü gibi katılımcıların geliştirilen modeli benimseme düzeyleri unvanlarına göre farklılık göstermezken $\left[U_{(382)}=6227.0, p>.05\right]$, Türk eğitim sisteminde uygulanabilir bulma düzeyleri farklılaşmaktadır $\left[U_{(382)}=4536.0, p<.05\right]$. Buna göre eğitim denetmenleri, eğitim denetmen yardımcılarına göre geliştirilen modelin Türk eğitim sisteminde daha çok uygulanabilir olduğu görüşündedirler.

Eğitim denetmenlerinin görüşlerinin kıdem ve görev yaptıkları bölge değişkenlerine göre değişip değişmediğini belirlemek için yapılan Kruskal-Wallis analizi sonuçları Tablo 4'te verilmiştir.

Tablo 4.

Eğitim Denetmenlerin Önerilen Modele Ilişkin Görüşlerinin Kıdem ve Görev Yaptıkları Bölge Değişkenlerine Göre Kruskal-Wallis Testi Sonuçları.

\begin{tabular}{|c|c|c|c|c|c|c|c|c|}
\hline Değişken & Boyut & Kategori & $\mathbf{N}$ & $\bar{X}$ & $x^{2}$ & Sd & $\mathbf{P}$ & Fark \\
\hline \multirow{6}{*}{$\begin{array}{l}\frac{\varepsilon}{d} \\
\frac{\partial}{2}\end{array}$} & \multirow[t]{3}{*}{ Benimseme } & $1-20$ yıl arası & 57 & 192.27 & \multirow[t]{3}{*}{0.416} & \multirow[t]{3}{*}{2} & \multirow[t]{3}{*}{.812} & \\
\hline & & $21-30$ yıl arası & 151 & 188.86 & & & & \\
\hline & & 31 yıl ve üzeri & 177 & 196.77 & & & & \\
\hline & \multirow{3}{*}{$\begin{array}{l}\text { Uygulanabilir } \\
\text { Bulma }\end{array}$} & $1-20$ yıl arası & 57 & 155.75 & \multirow[t]{3}{*}{11.530} & \multirow[t]{3}{*}{2} & \multirow[t]{3}{*}{.003} & $1-2$ \\
\hline & & $21-30$ yıl arası & 151 & 186.14 & & & & $1-3$ \\
\hline & & 31 yıl ve üzeri & 177 & 210.85 & & & & $2-3$ \\
\hline \multirow{14}{*}{ 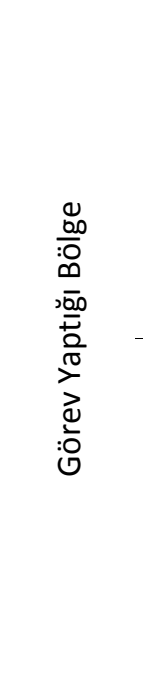 } & \multirow[t]{7}{*}{ Benimseme } & Akdeniz & 54 & 214.54 & \multirow[t]{7}{*}{17.081} & \multirow[t]{7}{*}{6} & \multirow[t]{7}{*}{.009} & $5-1$ \\
\hline & & Ege & 46 & 243.84 & & & & $5-2$ \\
\hline & & Doğu Anadolu & 48 & 193.27 & & & & $5-3$ \\
\hline & & Güneydoğu An. & 44 & 173.39 & & & & $5-4$ \\
\hline & & İç Anadolu & 61 & 167.20 & & & & $\begin{array}{l}5-6 \\
5-7\end{array}$ \\
\hline & & Karadeniz & 57 & 182.46 & & & & \\
\hline & & Marmara & 75 & 186.64 & & & & \\
\hline & \multirow{7}{*}{$\begin{array}{l}\text { Uygulanabilir } \\
\text { Bulma }\end{array}$} & Akdeniz & 54 & 227.41 & \multirow[t]{7}{*}{25.766} & \multirow[t]{7}{*}{6} & \multirow[t]{7}{*}{.000} & \multirow{7}{*}{$\begin{array}{r}3 \text { ve } 4 \\
\text { diğer tüm } \\
\text { bölgelerle }\end{array}$} \\
\hline & & Ege & 46 & 193.41 & & & & \\
\hline & & Doğu Anadolu & 48 & 142.22 & & & & \\
\hline & & Güneydoğu An. & 44 & 163.40 & & & & \\
\hline & & İç Anadolu & 61 & 173.89 & & & & \\
\hline & & Karadeniz & 57 & 213.43 & & & & \\
\hline & & Marmara & 75 & 217.86 & & & & \\
\hline
\end{tabular}

Tablo 4'te görüldüğü gibi katılımcıların geliştirilen modeli benimseme düzeyleri mesleki kıdemlerine göre değişmezken $\left[\chi_{(2)}^{2}=0.416, p>.05\right]$, Türk eğitim sisteminde uygulanabilir bulma düzeyleri farklılaşmaktadır $\left[\chi_{(2)}^{2}=11.530, p<.05\right]$. Buna göre eğitim denetmenlerinin mesleki kıdemleri arttıkça 
geliştirilen modelin Türk eğitim sisteminde uygulanabileceğine ilişkin görüşleri de olumlu yönde artmaktadır.

Yine Tablo 4'te görüldüğü gibi eğitim denetmenlerinin geliştirilen modeli benimseme $\left[\chi^{2}{ }_{(6)}=17.081\right.$, $p<.05]$ ve uygulanabilir bulma $\left[\chi_{(6)}^{2}=25.766, p<.05\right]$ düzeyleri görev yaptıkları bölgelere göre anlamlı olarak farklıık göstermektedir Buna göre iç Anadolu Bölgesindeki illerde görev yapan denetmenler, diğer bölgelerde görev yapan denetmenlere göre modeli daha düşük düzeyde benimsemişlerdir. Güneydoğu Anadolu ve Doğu Anadolu Bölgelerinde görev yapan denetmenler de diğer bölgelerde görev yapan denetmenlere göre önerilen modeli daha düşük düzeyde uygulanabilir bulmuşlardır.

\section{Açık Uçlu Soruya ilişkin Bulgular}

Eğitim denetmenlerine, geliştirilen ve önerilen eğitim denetimi modeline ilişkin görüş ve önerilerin istendiği açık uçlu soruda görüş bildiren denetmenlerin tamamı, daha çok önerilen modelin ideal bir model olduğu ve Türk eğitim sisteminde uygulanmaya geçilmesinin yaşanan sorunları azaltacağı yönünde görüş bildirmiştir. Modelde olmayan farklı bir öneri belirtilmemiştir. Yazılan bütün görüşler önerilen model ile örtüşsmektedir.

\section{Sonuç, Tartışma ve Öneriler}

Türkiye'de eğitim denetimi için yeni bir model geliştirmeyi ve geliştirilen yeni modelin eğitim denetmenleri tarafından ne düzeyde benimsendiğini ve uygulanabilir bulunduğunu belirlemeyi amaçlayan bu çalışma kapsamında, mevcut yerli ve yabancı literatür, yapılan araştırma sonuçları ve milli eğitim şuralarında alınan tavsiye kararları göz önünde bulundurularak bir eğitim denetimi modeli geliştirilmiştir. Model, eğitim denetiminin yapı ve süreç (işleyiş) boyutlarına ilişkin düzenlemeleri içermektedir. Daha sonra eğitim denetmenlerinin görüşüne sunulan model, eğitim denetmenlerince olumlu karşılanmıştır.

Araştırmaya katılan eğitim denetmenleri geliştirilen modelin, örgütsel yapılanmasını yansıtan yapı boyutunu tamamen benimsemiş ve Türk eğitim sisteminde uygulanabilir bulmuşlardır. Modelin yapı boyutunun denetmenlerce tamamen benimsenmesi ve Türk eğitim sisteminde uygulanabilir görülmesi, modelin Türkiye koşullarına uygun, gerçekçi ve ihtiyaca yönelik bir yapı sunduğunu göstermektedir. Benimseme ve uygulanabilir bulma düzeyinin bu kadar yüksek olmasında, modelin ikili denetim yapısı yerine bir birim tarafından koordine edilen tekli denetim yapısı önermesinin ve bakanlığın taşra teşkilatında denetimin bölgesel düzeyde yapılanmayı öngörmesinin ve uzmanlığa/branşa dayalı denetim gruplarına yer vermesinin etkisi olduğu söylenebilir. Nitekim sorulan açı uçlu soruya verilen tüm cevaplarda bu yönde görüşler belirtilmiş, bu denetim modeline biran önce geçilmesi yönünde görüşler ağırlık kazanmıştır.

Çalışmanın başlarında açıklandığı gibi yapılan araştırmalarda da eğitim denetmenliği ve bakanlık müfettişliği ayııımına son verilmesi, denetimin tek ad ve tek çatı altında birleştirilmesi, eğitim denetmenlerinin il milli eğitim müdürlüklerine bağı olarak çalışmalarına son verilmesi, rehberlik ve soruşturmanın aynı kişilerde toplanmasının öğretmen- müfettiş ilişkilerini olumsuz etkilediği sonuçlarına ulaşılmıştır (Can, 2004; Dağıı, 2004; Tok, 2004; Yıldırım, 2007). Ayrıca milli eğitim şuralarında ikili yapıya son verilerek denetimin tekli yapıda örgütlenmesi, (MEB, 2008a), denetimde bölge sistemine geçilmesi yönünde tavsiye kararları alınmıştır (MEB, 2008e). Bütün bu verilerden hareket edilerek, geliştirilen denetim modelinin Türk eğitim sisteminde uygulanmaya başlanması ile denetim sisteminde yaşanan sorunların önemli oranda azalacağı söylenebilir.

Araş̧ırmaya katılan eğitim denetmenleri geliştirilen modelin işleyişini, çalışma usul ve ilkelerini yansıtan süreç boyutunu da tamamen benimsemiş ve Türk eğitim sisteminde uygulanabilir bulmuşlardır. Bu bulgu, modelin çağın gereklerine uygun denetim ilkelerini ve çalışma usul ve esaslarını içerdiğinin göstergesi olarak değerlendirilebilir. Denetmenler, önerilen denetim modelinin süreç boyutu ile ilgili 
ifadeleri, yapı boyutundaki ifadelerden görece daha yüksek düzeyde benimsemiş ve uygulanabilir bulmuşlardır. Bunda, denetimin işleyişinde ve çalışma esaslarında yaşanan sorunların etkisi olduğu söylenebilir.

Denetime yüklenen anlam ve denetimden beklentiler konusunda, hem öğretmenler hem de denetmenlerce denetimin rehberlik ve yardım süreci olarak görülmemesi, dolayısıyla rehberlik yerine kontrol odaklı denetim uygulamalarının ağır basması, denetim sürecinde öğretmenler ve denetmenler arasında açık bir diyalogun ve yeterli işbirliğinin kurulamaması, denetim uygulamalarından yeterince verim alınmaması ve denetimin öğretim sürecini geliştirmekten uzak kalması, öğretmenlerin denetime soğuk bakması gibi hususlardan öğretmenler kadar denetmenlerin de rahatsızlık duyması doğaldır. Dolayısıyla önerilen yeni modele ilişkin bu denli yüksek düzeyde olumlu görüşlerin temelinde bunların etkisinin olduğu düşünülebilir. Yukarıda belirtildiği gibi birçok araştırmada da mevcut denetim sisteminin işleyişi ile ilgili önemli sorunların varlığına değinilmektedir. Bu araştırma sonuçları göz önünde bulundurulduğunda, denetmenlerin görev biçimi ve çalışma esaslarının, denetime yüklenen çağdaş anlamı yansıtan denetim ilkeleri doğrultusunda yeniden düzenlenmesi gerektiği açıktır. Dolayısıyla önerilen modelin, ihtiyaç duyulan bu düzenlemeleri içerdiği söylenebilir.

Araştırmada ulaşılan bulguya göre eğitim denetmenleri, eğitim denetmen yardımcılarına göre geliştirilen modelin Türk eğitim sisteminde daha çok uygulanabilir olduğu görüşündedirler. Eğitim denetmenlerinin, siteme yeni dahil olan denetmen yardımcılarına göre modeli daha yüksek düzeyde uygulanabilir bulmaları, alanı daha iyi tanımaları ile açıklanabilir. Ayrıca denetmen yardımcılarının daha çok Doğu ve Güneydoğu Anadolu bölgelerinde yer alan illerde çalışıyor olması, bulundukları bu illerde denetmen sayısının az olması nedeniyle iş yüklerinin daha çok olması, özlük hakları ve yer değiştirme ile ilgili yaşadıkları problemlerin de, sitemin yeniden yapılandırılması ile ilgili görüşlerinin, eğitim denetmenlerinin görüşlerine göre görece daha olumsuz olmasında etkili olduğu söylenebilir.

Araştırmada, eğitim denetmenlerinin mesleki kıdemleri arttıkça geliştirilen modelin Türk eğitim sisteminde uygulanabileceğine ilişkin görüşlerinin de olumlu yönde arttığı bulgusuna ulaşılmıştır. Eğitim denetmenlerinin, denetmen yardımcılarına göre daha kıdemli oldukları düşünülürse, bu bulgu unvan değişkeni ile ilgili bulguyla örtüşmektedir. Kıdemli olanların modeli daha yüksek düzeyde uygulanabilir bulmaları, alanı daha iyi tanımaları ile açıklanabilir. Ayrıca kıdemli denetmenlerin sitem içinde sorunlara daha uzun süre maruz kalmaları nedeniyle, yeni bir yapılanmaya duyulan ihtiyaç algılarının daha olduğu söylenebilir. Önerilen modelin yaşanan sorunlardan hareketle yapılandırılmış olmasının, denetmenlerin modeli tamamen benimsemesinde etkili olduğu düşünülmektedir.

Araştırmada ulaşılan başka bir bulguya göre İç Anadolu Bölgesindeki illerde görev yapan denetmenler, diğer bölgelerde görev yapan denetmenlere göre modeli daha düşük düzeyde benimsemişlerdir. İ̧ Anadolu Bölgesinde görev yapan denetmenlerin önerilen modeli benimseme düzeylerinin diğer bölgelere göre görece daha olumsuz çıkması, özellikle Kayseri ilinde görev yapan denetenlerin görüşlerinden kaynaklanmaktadır. Kayseri ilinde denetmenler derneğinin kurulmuş olması ve kurulan derneğin özellikle müfettişlerin özlük hakları, sistemin yeniden yapılandırılması gibi konularda yapmış olduğu çalışmaların istenilen sonuçları çabuk vermemiş olması gibi faktörlerin, sistemde köklü değişikliklere olan inancı zayıflatmış olma ihtimalinin bu araştırma ile ilgili sonuçlara da yansıdığı söylenebilir.

Araştırmada Güneydoğu Anadolu ve Doğu Anadolu Bölgelerinde görev yapan denetmenlerin diğer bölgelerde görev yapan denetmenlere göre önerilen modeli daha düşük düzeyde uygulanabilir buldukları bulgusuna ulaşılmıştır. Güneydoğu ve Doğu Anadolu Bölgeleri dışındaki bölgelerden elde edilen sonuçlar genel olarak birbirine yakındır. Güneydoğu ve Doğu Anadolu Bölgelerinde denetmen yardımcılarının sayısının çok olması, bu bölgelerde iş yükünün fazla olması, diğer bölgelerde denetmen kadrolarının dolu olmasından dolayı istedikleri illere atamalarının yapılamaması gibi nedenlerle, Türkiye'de denetim alt sisteminin yeniden yapılandırılması ile ilgili düzenlemelerin yapılabileceğine olan inançlarının görece daha olumsuz olduğu söylenebilir. 
Sonuç olarak denetim sisteminde yaşanan sorunlar, Türkiye'nin koşulları ve çağdaş eğitim anlayışı göz önünde bulundurularak geliştirilen, rehberlik ve eğitim sürecini geliştirme odaklı yeni eğitim denetimi modelinin, Türk eğitim sistemine önemli katkılar sunma potansiyelini taşıdığı; karar alıcıların yapacağı düzenlemelerde ve uygulayıcıların pratiklerinde yararlanabilecekleri bir model olduğu düşünülmektedir. Türkiye'deki eğitim denetmenlerinin bunu tamamen benimsemeleri ve Türkiye'de uygulanabilir bulmaları da bunun bir göstergesi olarak kabul edilebilir. Bu konuda eğitim denetimi alt sisteminin yapısal sorunları ve işleyişi ile ilgili, başta bu araştırmada yer almaktan kaçınan bakanlık müfettişleri olmak üzere, öğretmenler, eğitim denetmenleri, bakanlıktaki yöneticiler ve okul müdürleri gibi paydaşların görüşlerinin alındığı, nicel ve nitel yöntemlerin birlikte kullanıldığı araştırmaların yapılması yararlı olacaktır.

\section{Kaynakça}

Arabacı, I. B. (1995). Illköğretim müfettişlerinin denetim ilkeleri konusundaki yeterlikleri. Unpublished master thesis, Ankara Üniversitesi Eğitim Bilimleri Enstitüsü, Ankara.

Arslantaş, H. i. (2007). ilköğretim müfettişlerinin mesleki yardım ve rehberlik rollerinin öğretmen algılarına göre değerlendirilmesi. Unpublished doctoral dissertation, Gaziantep Üniversitesi Sosyal Bilimler Enstitüsü, Gaziantep.

Atay, K. (1995). Ilköğretim müfettişlerinin yeterlikleri. Unpublished doctoral dissertation, Atatürk Üniversitesi Sosyal Bilimler Enstitüsü, Erzurum.

Aydın, M. (1993). Çağdaş eğitim denetimi. Ankara: Pegem Akademi Yayınları.

Aydın, i. (2005). Öğretimde denetim: Durum saptama, değerlendirme ve geliştirme. Ankara: Pegem Akademi Yayınları.

Balaban, C. (2005). Aday öğretmenlerin işbasında yetiştirilmesinde ilköğretim müfettişlerinin rolü. Unpublished master thesis, Abant İzzet Baysal Üniversitesi Sosyal Bilimler Enstitüsü, Bolu.

Balcı, A., Aydın, İ., Yılmaz, K., Memduhoğlu, H.B. \& Apaydın Ç. (2007). Türk eğitim sisteminde ilköğretimin yönetimi ve denetimi: mevcut durum ve yeni perspektifler. Türkiye'de okul öncesi eğitim ve ilköğretim sistemi temel sorunlar ve çözüm önerileri. Ankara: Türk Eğitim Derneği Yayınları.

Başar, H. (2000). Eğitim denetçisi. Ankara: Pegem Akademi Yayınları.

Başaran, A. (2004). Türk milli eğitim teftiş sisteminde yeniden yapılanmaya gidilirken Milli Eğitim Bakanlığı'nda yeniden yapılanma. Eğitim denetiminde yeni yaklaşımlar. Ankara: Tem-Sen Yayınları.

Burgaz, B. (1995). Illköğretim kurumlarının denetiminde yeterince yerine getirilmediği görülen bazı denetim rolleri ve nedenleri. Hacettepe Üniversitesi Eğitim Fakültesi Dergisi, 11, 127-134.

Büyükışık, M. (1989). ilköğretim denetçilerinin rehberlik etkinliklerinin gerçekleşme düzeyleri. Unpublished master thesis, Hacettepe Üniversitesi Sosyal Bilimleri Enstitüsü, Ankara.

Can, N. (2004). İlköğretim öğretmenlerinin denetimi ve sorunları. Milli Eğitim Dergisi, 31(161), 112-122.

Ciğer, M. (2006). Kahramanmaraş ili, ilköğretim müfettişlerinin ders denetim sürecinde gösterdikleri davranışların öğretmenleri güdülemesine ilişkin öğretmen ve müfettiş görüşleri. Unpublished master thesis, Ankara Üniversitesi Eğitim Bilimleri Enstitüsü, Ankara.

Dağlı, (2004). İlköğretim denetmenlerinin eğitim ve yaşam ile ilgili karşılaştıkları sorunlar ve bu sorunların çözümüne ilişkin öneriler. XIII. Ulusal Eğitim Bilimleri Kurultayı, İnönü Üniversitesi, Eğitim Fakültesi, Malatya.

Dinçer, B. \& Özaslan, M. (2004). İlçelerin sosyo-ekonomik gelişmişlik sıralaması araştırması. Ankara: DPT Yayını.

Doğanay, E. (2006). Taşra birimlerindeki ilk ve ortaöğretim kurumlarında yürütülen teftiş hizmetlerinin karşılaştırılması. Unpublished master thesis, Yüzüncü Yıl Üniversitesi Sosyal Bilimler Enstitüsü, Van. 
Döngel, A. (2006). ilköğretimde denetim ve performans değerlendirme çalışmalarının web üzerinden iyileştirilmesine ilişkin ilköğretim müfettişlerinin görüşleri. Unpublished master thesis, Gazi Üniversitesi Eğitim Bilimleri Enstitüsü, Ankara.

Dündar, A. A. (2005). Illköğretim okullarında yapılan teftişin okul başarısı ve gelişimi üzerine etkisi. Unpublished master thesis, Gazi Üniversitesi Eğitim Bilimleri Enstitüsü, Ankara.

Ecevit, H. (1996). Ilköğretim müfettişlerinin, ilköğretim okullarında rehberlik ve iş başında yetiştirme etkinlikleri ve gerçekleştirme düzeyi. Unpublished master thesis, Gazi Üniversitesi Eğitim Bilimleri Enstitüsü, Ankara.

Eyi, T. F. (2007). Milli Eğitim Bakanlığı teftiş alt sisteminin yapısı, işleyişi ve yenileşme intiyacı. Eğitim ve Denetim Dergisi, 15, 23-25.

Gülcan, M. G. (2003). Avrupa Birliğine adaylık sürecinde Türkiye eğitim sisteminin yapısal sorunları ve yapısal uyum modeli araştırması. Unpublished doctoral dissertation, Ankara Üniversitesi Eğitim Bilimleri Enstitüsü, Ankara.

Gün, F. (1989). ilköğretim denetçilerinin soruşturma rollerinin rehberlik rollerini etkilemesi. Unpublished master thesis, Hacettepe Üniversitesi Sosyal Bilimleri Enstitüsü, Ankara.

Gündüz, Y. (2008). Avrupa Birliği'ne uyum sürecinde milli eğitim bakanlığı teftiş sisteminin yenilenme ihtiyacı. Unpublished doctoral dissertation, Marmara Üniversitesi Eğitim Bilimleri Enstitüsü, İstanbul.

ilğan, A. (2006). Adana, K. Maraş ve Hatay ili ilköğretim müfettişleri ve öğretmenlerinin farklıaştırılmış denetim modelini benimseme ve kamu ilköğretim okullarında uygulanabilir bulma düzeyleri. Unpublished doctoral dissertation, Ankara Üniversitesi Eğitim Bilimleri Enstitüsü, Ankara.

Karakış, M. (2007). ilköğretimde güncel denetim duruşunun öğretmenlik bilincini uyandırma yeterliliğine ilişkin öğretmen görüşlerinin değerlendirilmesi. Unpublished master thesis, Dicle Üniversitesi Sosyal Bilimler Enstitüsü, Diyarbakır.

Kartal, S. (1997). Illköğretim ikinci kademe branş öğretmenlerinin teftiş-rehberlik etkinlikleri hakkındaki görüşleri. Unpublished master thesis, Gazi Üniversitesi Eğitim Bilimleri Enstitüsü, Ankara.

Kapusuzoğlu, Ş (2008). Okula dayalı yönetimde denetim sisteminin işlevselliği ve katkısının değerlendirilmesi. Abant İzzet Baysal Üniversitesi Sosyal Bilimler Enstitüsü Dergisi, 1(16), 13-140

Kavas, E. (2005). Ilköğretim müfettişlerinin denetim davranışlarına ilişkin öğretmen algı ve beklentileri. Unpublished master thesis, Pamukkale Üniversitesi Sosyal Bilimler Enstitüsü, Denizli.

Kimbrough, R. B. \& Burkett, C. W. (1990). The principalship: Concepts and practices. New Jersey: England Cliffs Prentice Hall.

Kowalski, T. J. \& Brunner, C. C. (2005). The school superintendent: Roles, challenges, and issues. In F. W. English (Ed.). The SAGE handbook of educational leadership: Advances in theory, research, and practice (pp. 142-167). London, New Delhi: Sage Publications.

Korkmaz, M. (2007). ilköğretim müfettişlerinin rehberlik görevlerini yerine getirme düzeyleri. Unpublished master thesis, Onsekiz Mart Üniversitesi Sosyal Bilimler Enstitüsü, Çanakkale.

Koruç, S. (2005). Illköğretim kurumlarında klinik denetim modeli önerisi. Unpublished master thesis, Dumlupınar Üniversitesi Sosyal Bilimler Enstitüsü, Kütahya.

MEB (2008a). Onbirinci milli eğitim şura kararları. Retrieved December 04, 2008, from The Ministry of National Education (MoNE),Web site: http://ttkb.meb.gov.tr/semceler/sura/11 sura.pdf.

MEB (2008b). Onikinci milli eğitim şura kararları. Retrieved December 04, 2008, from The Ministry of National Education (MoNE),Web site: http://ttkb.meb.gov.tr/ secmeler/sura/12 sura.pdf.

MEB (2008c). Ondördüncü milli eğitim şura kararları. Retrieved December 04, 2008, from The Ministry of National Education (MoNE),Web site: http://ttkb.meb.gov.tr/secmeler/sura/14_sura.pdf.

MEB (2008d). Onbeşinci milli eğitim şura kararları. Retrieved December 04, 2008, from The Ministry of National Education (MoNE),Web site: http://ttkb.meb.gov.tr/ secmeler/sura/15 sura.pdf. 
Hasan Basri MEMDUHOĞLU ve Abdulhakim TAYMUR - Pegem Eğitim ve Öğretim Dergisi, 4(2) 2014, 25-44

MEB (2008e). Onyedinci milli eğitim şura kararları. Retrieved December 04, 2008, from The Ministry of National Education (MoNE),Web site: http://ttkb.meb.gov.tr/secmeler/sura/17 sura.pdf.

Memduhoğlu, H. B., Aydın, I., Yılmaz, K., Güngör, S. \& Oğuz, E. (2007). The process of supervision in the Turkish educational system: Purpose, structure, operation. Asia Pacific Education Review, 8(1), 5670.

Memduhoğlu, H. B. \& Taymur, A. (2009, Haziran). Türk eğitim sistemi denetim alt sisteminin yeniden yapılandırılmasına ilişsin bir model önerisi. Uluslararası Katılımlı Ulusal Eğitim Denetimi Kongresi, Ankara.

Memduhoğlu H. B. \& Zengin M. (2012). Çağdaş eğitim denetimi modeli olarak öğretimsel denetimin Türk eğitim sisteminde uygulanabilirliği. Kuramsal Eğitimbilim Dergisi, 5(1), 131-142.

Memişoğlu, S. P. (2001). Çağdaş eğitim denetimi ilkeleri açııından ilköğretim okullarında öğretmen denetimi uygulamalarının değerlendirilmesi. Unpublished doctoral dissertation, Abant İzet Baysal Üniversitesi Sosyal Bilimler Enstitüsü, Bolu.

Nelson, B., S. \& Sassi, A. (2000). Shifting approaches to supervision: The case of mathematics supervision. Educational Administration Quarterly, 36(4), 553-584.

Olgun, R. (2005). Illköğretim okulu müdür ve müdür yardımcılarının ilköğretim müfettişlerinin yapmış olduğu denetim etkinliklerine ilişskin görüşleri. Unpublished master thesis, Kırıkkale Üniversitesi Sosyal Bilimler Enstitüsü, Kırıkkale.

Pınardağ, M. (2005). Bakanlık müfettişlerimiz kendi işlerini bırakmışlar başkasının sahasında geziyorlar. Eğitim ve Denetim Dergisi, 6, 4-5.

Sabancı, A. \& Günbayı, İ. (2004). Ilköğretim denetmenlerinin görev alanlarının ve yüklerinin yeterlik alanları açısından değerlendirilmesi. Akdeniz Üniversitesi Eğitim Fakültesi Dergisi, 1, 114-121.

Sarı, K. (1987). Milli Eğitim Bakanlığında görevli ilköğretim müfettişlerinin örgütlerindeki yönetim uygulamalarını algılamaları ile iş doyumları arasındaki ilişkiler. Unpublished doctoral dissertation, Abant İzzet Baysal Üniversitesi Sosyal Bilimler Enstitüsü, Bolu.

Sergiovanni, T. J., \& Starratt, R. J. (2002). Supervision: A redefinition (7th ed.). NY: Mc Graw Hill.

Şahin, T. (2005). ilköğretim düzeyinde ders denetimi ile ilgili yeterlilikler hakkında denetmen ve öğretmen görüşleri. Unpublished master thesis, Abant İzzet Baysal Üniversitesi Sosyal Bilimler Enstitüsü, Bolu.

Swaffield, S. \& MacBeath, J. (2005). School self-evaluation and the role of a critical friend. Cambridge Journal of Education, 35(2), 239-252.

Taşar, H. H. (2000). Ilköğretim müfettişlerinin rehberlik görevlerine ilişkin sorunları. Unpublished master thesis, Gaziantep Üniversitesi Sosyal Bilimler Enstitüsü, Gaziantep.

Taymaz, H. (2002). Eğitim sisteminde teftiş: Kavramlar, ilkeler, yöntemler. Ankara: Pegem A Yayıncllık.

Taymaz, H. (2005). Eğitim sisteminde teftiş: Kavramlar, ilkeler, yöntemler (6.Baskı). Ankara: Pegem A Yayıncilık.

Tok, T. N. (2004). ilköğretim müfettişlerinin iş doyumu ve örgütsel bağlılkları. Unpublished doctoral dissertation, Ankara Üniversitesi Eğitim Bilimleri Enstitüsü.

Uyanık, M. (2007). Ders teftişinde müfettiş uzmanlaşmasının önemi. Unpublished master thesis, Muğla Üniversitesi Sosyal Bilimler Enstitüsü, Muğla.

Uygur, D. (2006). ilköğretim okullarında aday öğretmenlerin yetiştirilmesinde ilköğretim müfettişlerinin rolleri. Unpublished master thesis, Ankara Üniversitesi Eğitim Bilimleri Enstitüsü, Ankara.

Ünal, A. (1999). Ilköğretim denetçilerinin rehberlik rolünü gerçekleştirme yaklaşımları. Unpublished master thesis, Ankara Üniversitesi Sosyal Bilimler Enstitüsü, Ankara.

Weiss, E. M. \& Weiss, S. (2001). Doing reflective supervision with student teachers in a professional development school culture. Reflective Practice, 2(2), 125-154. 
Hasan Basri MEMDUHOĞLU ve Abdulhakim TAYMUR - Pegem Eğitim ve Öğretim Dergisi, 4(2) 2014, 25-44

Yavuz, Y. (1995). Öğretmenlerin denetim etkinliklerini klinik denetim ilkeleri açısından değerlendirmeleri. Unpublished master thesis, Dokuz Eylül Üniversitesi Sosyal Bilimler Enstitüsü, İzmir.

Yıldırım, G. (2007). Sosyal Bilgiler öğretmenlerinin ders denetimine ilişkin görüşleri. Unpublished master thesis, Muğla Üniversitesi Sosyal Bilimler Enstitüsü, Muğla.

Zepeda, S. J. (2001). At odds: Can supervision and evaluation co-exist? The Journal of Cases in Educational Leadership, 4(1). 1-13.

Zepeda, S. J. (2002). Linking portfolio development to clinical supervision: A case study. Journal of Curriculum and Supervision, 18(1), 83-102. 